\title{
ポリスチレンスルホン酸ナトリウムおよび硫酸セルロース ナトリウムの水溶液粘度におよほす尿素の効果*1
}

(昭 和 45 年 3 月 30 日 受 理)

\author{
須 沢 利 郎・塩田 宏 治*2
}

\begin{abstract}
高分子電解質に対する尿素の作用機構を研究するため, 高分子電解質としてポリスチレンスルホン酸ナトリウム怙よび硫酸セル ロースナトリウム塩を用い, $30^{\circ} \mathrm{C}$ に拈いてその水溶液粘度に及济す尿素の効果を調べた。

水溶液中で尿素の分解がかなり進行し, 分解イオン濃度が大きいと考えられる場合には, 尿素濃度の增加とともに $\eta_{\mathrm{sp}} / c_{\mathrm{p}} \sim c_{\mathrm{p}}$ 曲 線 $\left(c_{\mathrm{p}}\right.$ : 高分子電解質濃度) は, 分解イオンによる電荷遮へい効果によって低下し, 高分子電解質分子の収縮が示唆された。しか し分解がほとんど進行せず，水溶液中に括ける分解イオン濃度が非常に小さいと考えられる場合には，尿素濃度の增加とともに， $\eta_{\mathrm{sp}} / c_{\mathrm{p}} \sim c_{\mathrm{p}}$ 曲線は上年し，尿素水溶液は高分子電解質に対して良溶媒として作用することが示唆された。また尿素濃度の增加とと もに $\eta_{\mathrm{sp}} / c_{\mathrm{p}} \sim c_{\mathrm{p}}$ 曲線が上身する程度は, 硫酸セルロースナトリウム塩の方がポリスチレンスルホン酸ナトリウム塩の場合よりも大 きいが，これは前者の分子内水素結合が尿素によって切断されることが原因であるらと考学られた。
\end{abstract}

\section{1 緒‧言}

尿素は, タンパク質や核酸などの生体高分子の二次構造の研究 やポリビニルアルコールのような非電解質高分子の分子内水素絬 合の切断試薬として用いられているが，通常の高分子笔解質に対 するその作用効果についての砰究は，実用的な方面——たと党ば 捺染なと一—との関逨に怙いても重要であるにもかかわらず少な く，またその作用機满も必らずしも明確ではない1 4。

そこで著者らはさきに高分子電解質としてポリビニルアルコー ル硫酸エステルナトリウム塩とカルボキシメチルセルロースナト リウム塩を用いて, その水溶液粘度に牤上ぼす尿素の効果を調

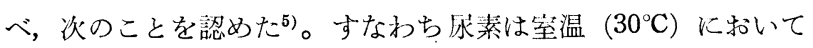
も水溶液中で分解し，シアン酸アンモニウムないし炭酸アンモニ ウムを生じ，その解離によってイオン強度が增大すること。高分 子電解質水溶液の粘度は，尿素添加により低下するが，それは尿 素の分解により生じた分解イオンが，中性塩添加の場合と同じく 高分子電解質の電荷遮へい効果をもたらし, 結果的に高分子電解 質が収縮するためであること。また尿素分解の経時変化を考虑し ない場合には, 高分子電解質の水溶液粘度が尿素濃度に上って不 規則に増減するが，尿素分解の経時変化を考虑すれば，尿素濃度 の増加とともにその粘度は規則的に低下することなど。

本研究ではさらに高分子電解質に対する尿素の作用機構を研究 するため, 高分子電解質としてポリスチレンスルホン酸ナトリウ ムおよび硫酸セルロースナトリウム塩を用い, $30^{\circ} \mathrm{C}$ に扣いてそ の水溶液粘度に及ぼす尿素の効果一一特にとの尿素水溶液調製後 の時間がかなり短かく，分解がほとんど進行していない場合につ いて—をより詳細に検討した。

*1 前報, 須沢利郎, 野村洋一, 元山光雄, 塩田宏治, 工化, 73, 209 (1970).

*2 Toshiro SUZAwA, Koji SHIODA 広島大学工学部: 広島 市千田町.

1) B. E. Conway, J.Polym.Sci., 20, 299 (1956).

2) J. Eliassaf, A.Silberberg, J. Polym.Sci., 41, 33 (1959).

3) G. Barone, V.Crescenzi, F. Quadrifoglio, La.Ric. Sci., 36, $482(1966)$.

4) 磯 晃二郎, 日化, 84, 201 (1963).

5）須沢利郎, 野村洋一, 元山光雄, 塩田宏治, 工化, 73, 209 (1970).

\section{2 実験}

\section{$2 \cdot 1$ 試 料}

ポリスチレンスルホン酸ナトリウム (Na-PSS と略)：原料ポ リスチレンとしてはスチレックスフィルム（三菱樹脂製）を用 い, 香川ら ${ }^{6}$ によって報告されている硫酸一硫酸銀法により合成し た。その条件としては，原料ポリスチレンフィルム（細断して使 用） $10 \mathrm{~g}, 95 \%$ 硫酸 $100 \mathrm{ml}$, 硫酸銀 $0.5 \mathrm{~g}$ 使用し，反応温度 $100^{\circ} \mathrm{C}$, 反応時間 5 6 時間とした。得られた岜とモ状の反灾生 成物を水溶解し，透析执よび電気透析により精製し，得たポリ スチレンスルホン酸水溶液を Amberlite IR-120 B (Na 型) カチ オン交換樹脂中を流下させ， $\mathrm{Na}$ 塩として調製，供試した。スル ホン化度は上記酸型試料を $\mathrm{N} / 10-\mathrm{NaOH}$ で中和して求めた。スル ホン化度 0.810 。重合度 $P$ は中川ら いて求められている次式により求めた。粘度平均重合度 1513 。

$$
[\eta]_{0.5 \mathrm{~N}-\mathrm{NaCl}}=5.75 \times 10^{-4} \mathrm{P} \quad\left(25^{\circ} \mathrm{C}\right)
$$

硫酸セルロースナトリナム塩 (Na-CS と略) : 原料セルロース としてはパルプ（山陽パルプ製， $\alpha$-瀻維素 $95.2 \%$ ，銅洒 $0.3 \%$ ) を用い, Fuelneggらによって報告されているクロルスルホン酸一 ピリジン法8)により硫酸化して合成した。まず板状パルプを水中 に投入して完全にほぐし，これを $3 \mathrm{~N}-\mathrm{NaOH} に 1$ 時間浸漬，口 別後多量の水で水洗して大部分のカセイソーダを除去し，ついで 希酢酸水溶液に浸漬, 水洗, さらにエタノールに浸漬口別し, 風 乾，真空乾燥したものを原料セルロースとした。合成条件として は原料セルロース $10 \mathrm{~g}$ ，ピリジン $130 \mathrm{ml}$ ，クロルスルホン酸 40 $\mathrm{m} l$ を使用し, 反応温度 $75 \sim 80^{\circ} \mathrm{C}$, 反応侍間 5 時間とした。得ら れた黄白色の粘稠な反応生成物を水に溶解, 口過, 口液をメタ, 一ル中に滴下して白色繊維状物を得る。この硫酸セルロースピリ ジニウム塩水溶液汇カセイソーダを添加，ピリジンを遊離させて 硫酸セルロースナトリウム塩水溶液とし，その後数回メタノール 再沈法を行ない精製, 真空乾燥したものを供試した。エステル化 度は含有 $\mathrm{Na} \mathrm{Na}_{2} \mathrm{SO}_{4}$ に変えて重量法によって求めた8)。エス

6）高橋 彰, 下山湊一, 香川毓美, 工化, 61, 1617 (1958).

7) M. Kato, T. Nakagawa, H. Akamatu, Bull. Chem. Soc. Jap., 33, 322 (1960).

8) E. G. Fuelnegg, O. Dingler, J. Amer. Chem. Soc., 52, 2849 (1930). 
テル化度 0.521 。また粘度平均重合度は, 香川ら 9 ) と同様, 供試 $\mathrm{Na}-\mathrm{CS}$ についての $2 \mathrm{~N}-\mathrm{NaOH}$ 中での還元粘度測定值より [ク] $(=1.09)$ を求め, 別に香川ら ${ }^{9,10)}$ によって得られているェステル 化度と $K_{\mathrm{m}}$ （高分子の種類抏よび溶媒により变化する定数）の関 係曲線より, $K_{\mathrm{m}}\left(=4.4 \times 10^{4}\right)$ を求め, Staudinger の式 $[\eta]=$ $K_{\mathrm{m}} \cdot P(P$ : 重合度 $)$ にそれぞれの值を代入して求めた。粘度平 均重合度 $248\left(25^{\circ} \mathrm{C}\right)$ 。

尿素：試薬特級品をエタノールより再結晶して使用。

塩化ナトリナム：試薬特級品を乾燥して使用。

$2 \cdot 2$ 実験方法

粘度 : $30^{\circ} \mathrm{C}$ で, 流下時間 59.15 秒のオストワルド粘度計を用 いて，常法により行なった。Na-PSS 水溶液の調製は，液状で貯 蔵された原液を, 純水で所定の濃度に希釈して行なった。 Na-CS 水溶液の調製は, 一定量の粉末試料を純水に溶解して原液とし, 希釈法によって測定濃度の溶液とした。ただし以下に述べるよう に, 実験条件に応じて実際の測定溶液の調製法括よび尿素水溶液 調製後粘度測定末での時間を変化させた。

\section{3 実験結果と考察}

\section{$3 \cdot 1 \eta_{\mathrm{sp}} / c_{\mathrm{p}} \sim c_{\mathrm{p}}$ 曲線におよぼす尿素濃度の効果}

$3 \cdot 1 \cdot 1$ 尿素水溶液調製後の時間を考慮しない場合 前報占に括 いてポリビニルアルコール硫酸エステルナトリウム塩 $(\mathrm{Na}-\mathrm{PVS}$ と略）打よびカルボキシメチルセルロースナトリウム塩（Na$\mathrm{CMC}$ と略）のような高分子電解質の水溶液粘度が，尿素分解の 経時変化を考慮しない場合には尿素濃度の増加によって不規則に 増減するが，尿素分解の経時変化を考慮すれば尿素濃度の増加と ともに規則的に低下することを認めた。そこで本研究でも $\eta_{\mathrm{sp}} / c_{\mathrm{p}}$ $\sim c_{\mathrm{p}}\left(c_{\mathrm{p}}\right.$ : それぞれの高分子電解質濃度）曲線におよぼす尿素濃 度の効果を調べるにあたって, 前報と同様まず尿素水溶液調製後

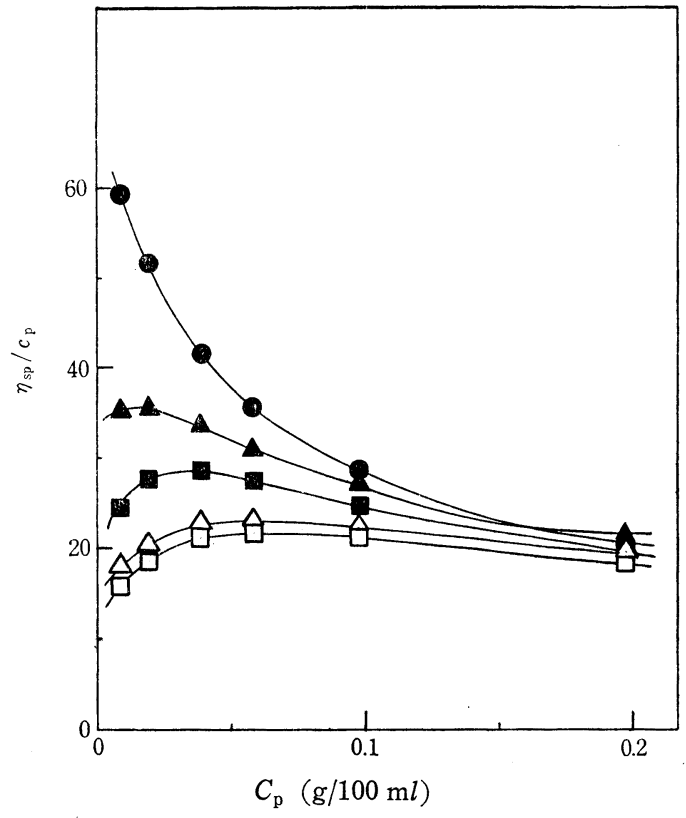

図 $1 \quad \eta_{\mathrm{sp}} / c_{\mathrm{p}} \sim c_{\mathrm{p}}$ 曲線に拈よぼす尿素濃度の影響 (Na-PSS の場合)

尿素淡度 $(\mathrm{mol} / \mathrm{l}) \bullet: 0, \mathbf{\square}: 1, \square: 2, \boldsymbol{\Delta}: 3, \triangle: 4$

9）香川毓美, 渡辺秀能, 工化, 52, 56 (1949).

10）香川毓美, 福田 守, 工化, 54, 98 (1951).

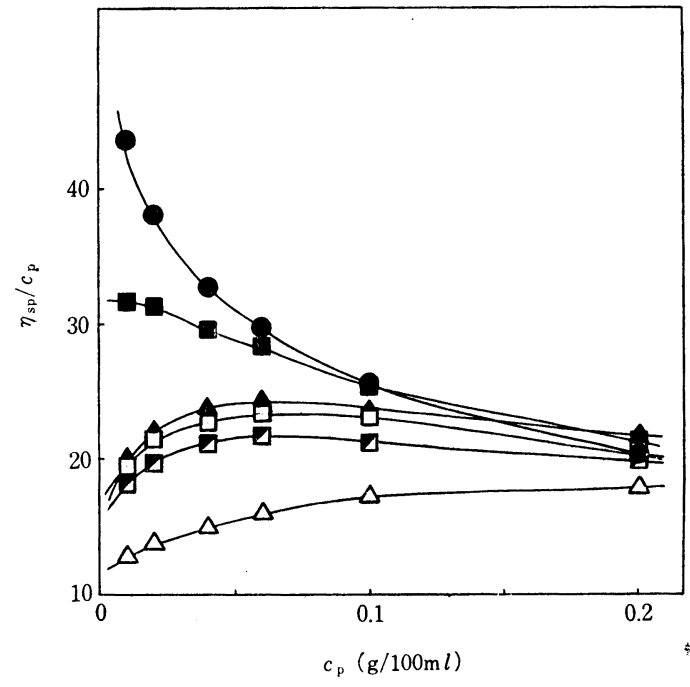

図 $2 \quad \eta_{\mathrm{sp}} / c_{\mathrm{p}} \sim c_{\mathrm{p}}$ 曲線に拈よ汪す尿素濃度の影響 ( Na-CS の場合)

尿素濩度 $(\mathrm{mol} / \mathrm{l}) \bigcirc: 0, \square \square: 1, \square: 2, \boldsymbol{\Delta}: 3, \triangle: 4$

の時間を考虑しない場合について測定を行なった。すなわち高分 子電解質水溶液および尿素水溶液は測定濃度の 2 倍濃度の溶液を つくり，これらを等量混合して用い，その際それぞれの水溶液調 製後粘度測定までの時間について考慮せずに粘度測定を行なっ た。図 1 扰よび図 2 はそれぞれ Na-PSS と Na-CS の $\eta_{\mathrm{sp}} / c_{\mathrm{p}} \sim c_{\mathrm{p}}$ 曲線におよぼす尿素添加の効果を示す。

図示したよ $5 に ，$ 尿素無添加の場合には， $\eta_{\mathrm{sp}} / c_{\mathrm{p}} \sim c_{\mathrm{p}}$ 曲線は低 濃度側で著しく上昇し高分子電解質特有の挙動を示す。しかし尿 素添加によって, いづれの場合も $\eta_{\mathrm{sp}} / c_{\mathrm{p}} \sim c_{\mathrm{p}}$ 曲線は尿素無添加の 場合と比較して低濃度側で低下した。これは通常の中性塩添加の 場合と外観上同様の効果であるが，中性塩の場合と比較してその 効果はかなり小さい。またこの際 $\eta_{\mathrm{sp}} / c_{\mathrm{p}} \sim c_{\mathrm{p}}$ 曲線は前報5)の $\mathrm{Na}-$ PVS 拈よび Na-CMC の場合と同様, 尿素濃度の増加とともに不 規則に上下し，またその測定值には再現性が認められなかった。 再現性のない点については，たとえば図 2 に拈ける Na-CS の場 合, 同じ $1 \mathrm{~mol} / l$ の尿素添加でも, 黒角印の尿素水溶液調製後の 時間が短かい場合の粘度が, 半黒角印の尿素水溶液調製後の時間 の長い場合のそれょりも大きいことからも推測される。

$3 \cdot 1 \cdot 2$ 尿素水溶液調製後の時間を 15 時間一定とした場合 前 項のように, 尿素水溶液調製後の時間を考慮しない場 合には, $\eta_{\mathrm{sp}} / c_{\mathrm{p}} \sim c_{\mathrm{p}}$ 曲線が尿素濃度の増加とともに不規則に上下したので, 次に尿素水溶液調製後粘度測定までの時間をすべて 15 時間とし， 前項と同様な実験を行なった。その結果を図 3 および図 4 に示 市。

図示したように, Na-PSS の場合も $\mathrm{Na}$-CS の場合もともに, 図 1 および図 2 にみられたような尿素濃度による $\eta_{\mathrm{sp}} / c_{\mathrm{p}} \sim c_{\mathrm{p}}$ 曲線 の不規則な上下関係はあらわれず, 尿素濃度の増加とともに $\eta_{\mathrm{sp}} /$ $c_{\mathrm{p}} \sim \mathrm{c}_{\mathrm{p}}$ 曲線は規則的に低下した。

上述の結果括よび前項の図 1 および図 2 の結果は, 前報5) と同 様, 尿素はその水溶液中に拈いて室温付近に括いても分解し, そ の分解に経時変化があり, 生じた分解イオンが中性塩添加の場合 と同じく高分子電解質に対して電荷遮へい効果を及ぼすために, 結果的に高分子電解質分子が収縮すると考えればよく説 明でき 


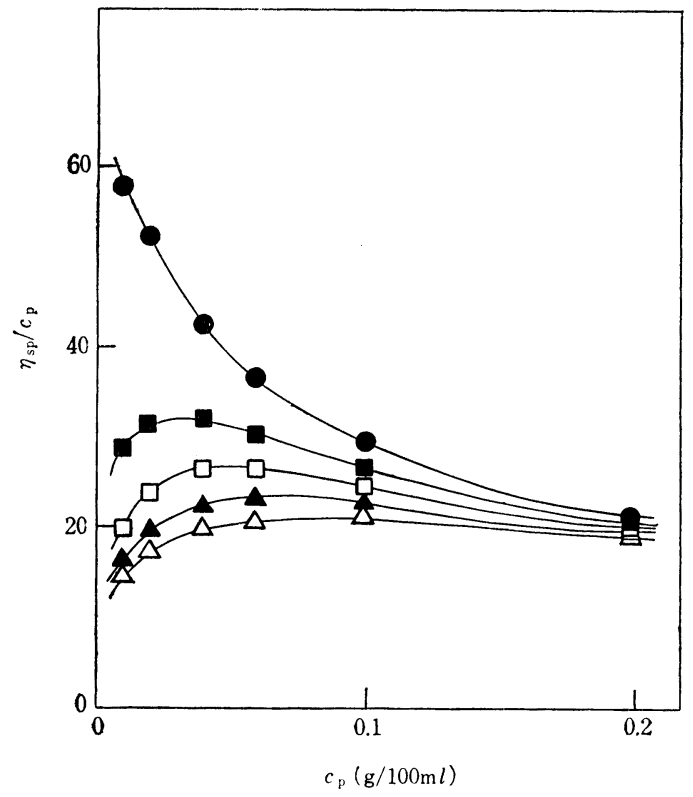

图 $3 \quad \eta_{\mathrm{sp}} / c_{\mathrm{p}} \sim c_{\mathrm{p}}$ 曲線に拈よぼす尿素濃度の影響 (尿素水溶液調製後 15 時間, Na-PSS) 尿素濃度 $(\mathrm{mol} / \mathrm{l})$

$\square: 1, \square: 2, \triangle: 3, \triangle: 4$

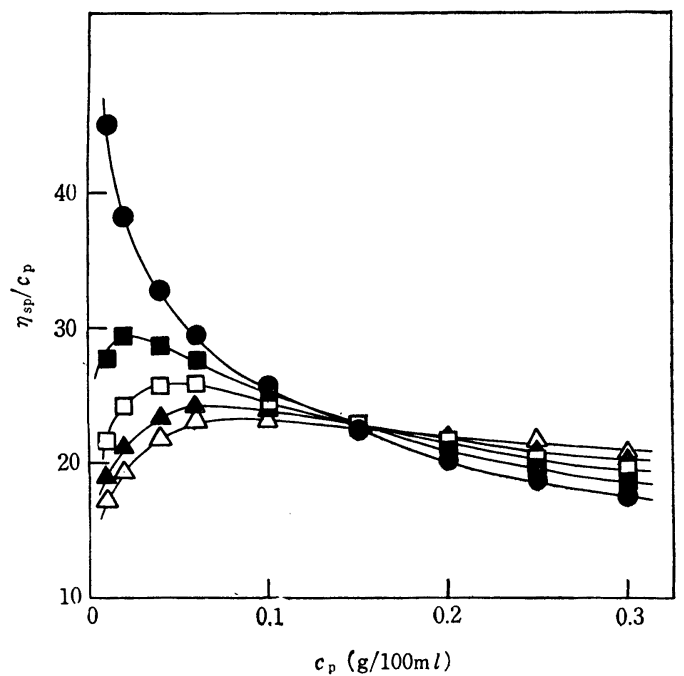

図 $4 \quad \eta_{\mathrm{sp}} / c_{\mathrm{p}} \sim c_{\mathrm{p}}$ 曲線に扣よぼす尿素濃度の影響 (尿素水溶液調製後 15 時間, $\mathrm{Na}-\mathrm{CS}$ ) 氺素湛度 $(\mathrm{mol} / \mathrm{l}) \bullet: 0, \boldsymbol{\square}: 1, \square: 2, \boldsymbol{\Delta}: 3, \triangle: 4$

る。

ここで図 4 の Na-CS の場合に, $c_{\mathrm{p}}$ が約 $0.15 \mathrm{~g} / 100 \mathrm{ml}$ 付近 で, $\eta_{\mathrm{sp}} / c_{\mathrm{p}} \sim c_{\mathrm{p}}$ 曲線に対する尿素濃度の効果が反転し，この $c_{\mathrm{p}}$ 以上では尿素濃度の増加とともに $\eta_{\mathrm{sp}} / c_{\mathrm{p}} \sim c_{\mathrm{p}}$ 曲線はほぼ上昇し た。この現象については後に検討する。

$3 \cdot 1 \cdot 3$ 尿素水溶液調製後の時間を 30 分一定とした場合 前項 では尿素水溶液調製後粘度測定までの時間をすべて 15 時間とし たが，次に尿素水溶液調製後かなり短時間の間に粘度測定を行な った場合の $\eta_{\mathrm{sp}} / c_{\mathrm{p}} \sim c_{\mathrm{p}}$ 曲線におよぼす尿素濃度の効果を調べるた め, 尿素水溶液調製後の時間を 30 分一定として前項と同様に粘 度を測定した。その結果を図 5 㧊よび図 6 に示す。

図からわかるように Na-PSS および Na-CS ともに, 尿素濃度 の增加とともに $\eta_{\mathrm{sp}} / c_{\mathrm{p}} \sim c_{\mathrm{p}}$ その曲線は規則的に上昇した。ただし

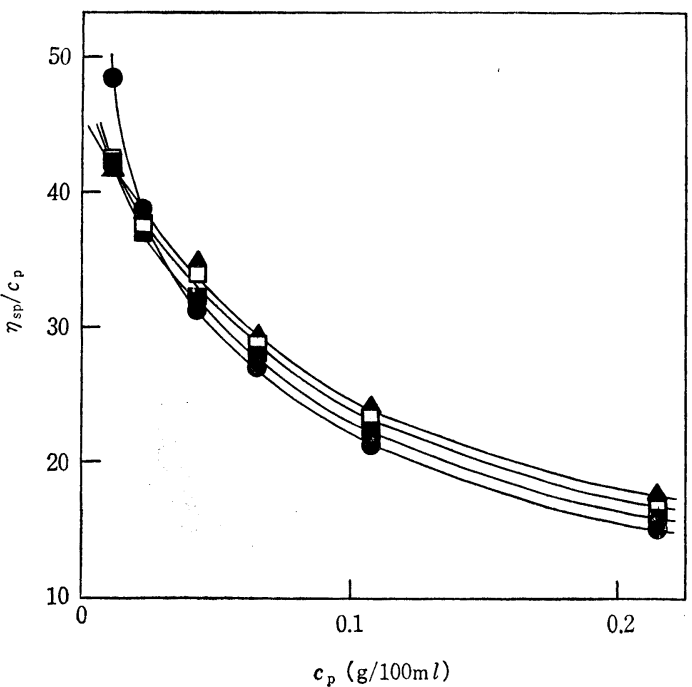

図 $5 \eta_{\mathrm{sp}} / c_{\mathrm{p}} \sim c_{\mathrm{p}}$ 曲線に括よぼす尿素濃度の影響 (尿素水溶液調製後 30 分, Na-PSS) 尿素港度 $(\mathrm{mol} / \mathrm{l}) \bullet: 0, \boldsymbol{\square}: 1, \square: 2, \boldsymbol{\Lambda}: 3$

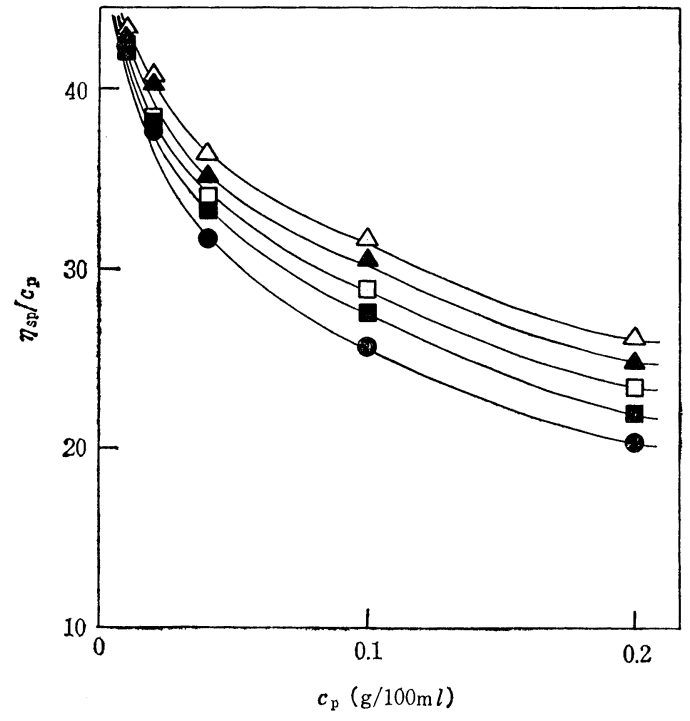

図 $6 \quad \eta_{\mathrm{sp}} / c_{\mathrm{p}} \sim c_{\mathrm{p}}$ 曲線に打よ活す尿素濃度の影響 (尿素水溶液調製後 30 分, $\mathrm{Na}-\mathrm{CS}$ )

尿素漕度 $(\mathrm{mol} / \mathrm{l}) \bullet: 0, \boldsymbol{\square}: 1, \square: 2, \boldsymbol{\Delta}: 3, \triangle: 4$

$\mathrm{Na}-\mathrm{PSS}$ の場合には Na-CS の場合よりもその上昇の程度は小さ く，またその濃度がかなり低い場合には $\eta_{\mathrm{sp}} / c_{\mathrm{p}} \sim c_{\mathrm{p}}$ 曲線は尿素濃 度の增加とともに低下する傾向を示す。

尿素濃度の增加とともに $\eta_{\mathrm{sp}} / c_{\mathrm{p}} \sim c_{\mathrm{p}}$ 曲線が規則的に上昇した原 因としては，尿素水溶液調製後の時間が短かいために，前報5)で 述べた尿素分解により生じた分解イオンが高分子電解質イオンに 対し，電荷遮へい効果を及ぼすよりも，尿素水溶液が高分子電解 質に対して良溶媒として作用する効果の方が大きく影響したため と考兄られる。すなわち尿素水溶液調製後 30 分に拈いても尿素 の分解がまったく抗こっていないわけではないが，それによって 生じた分解イオン濃度は高分子電解質の濃度に対しては相対的に 微小で, $\eta_{\mathrm{sp}} / c_{\mathrm{p}} \sim c_{\mathrm{p}}$ 曲線を低下させる原因とはなり得ないと考党 られる。それに対して大部分の未分解の尿素は，水の網目構造の 中に入りその構造を破壊することによって，結果的に高分子電解 
質に対して水を良溶媒化したと考えられよう。従って最近明らか にされつつある尿素による，水構造の規則性の破壊がこの場合に も結果的に関与寸るのであろうと推測される

また $\eta_{\mathrm{sp}} / c_{\mathrm{p}} \sim c_{\mathrm{p}}$ 曲線が尿素濃度の増加とともに上昇する程度が $\mathrm{Na}-\mathrm{CS}$ の方が Na-PSS の場合よりも大きい原因としては, 後者 の場合に考兄られない分子内水素結合の可能性が前者に招いては 考兄られ，そしてポリビニルアルコール水溶液粘度に対する尿素 の作用の場合 ${ }^{15)}$ と同様に，この Na-CS の場合の分子内水素結合 が尿素によって切断されることにあると考旮れば説明できる。

ここで前項の図 4 の Na-CS の場合に，その濃度 $0.15 \mathrm{~g} / 100 \mathrm{ml}$ を境として， $\eta_{\mathrm{sp}} / c_{\mathrm{p}} \sim c_{\mathrm{p}}$ 曲線に対する尿素の効果が異なり，尿素 濃度の増加とともに， $c_{\mathrm{p}}$ がこの濃度より大きい場合に，この曲線 が上昇したが，これは，この項での結果より考学て，第一に NaCS 濃度の増大によって，尿素の分解イオン濃度に対する高分子 電解質濃度が相対的に大きくなること，第二に Na-CS の場合に 考光られる分子内水素結合が尿素によって切断されること，など がその原因ではないかと考学れれ。

$3 \cdot 1 \cdot 4$ 尿素水溶液調製後の時間を 30 分一定とし，塩化ナトリ ウム存在の場合 前項に拈いて，尿素水溶液調製後の時間が 30 分一定の場合に, $\eta_{\mathrm{sp}} / c_{\mathrm{p}} \sim c_{\mathrm{p}}$ 曲線が尿素濃度の増加とともに規則 的に上昇するのがみられ，それは高分子電解質に対して尿素水溶 液が良溶媒として作用するのが原因と考兄られたが，さらにこの ことを明らかにするために，塩化ナトリウムのような中性塩を大 量に加兄，用いた高分子電解質を実質的に高分子非電解質として 挙動させるような条件下で，同様の実験を行なった。すなわち $6 \times 10^{-8} \mathrm{~mol} / l$ の塩化ナトリウムの存在下で，尿素水溶液調製後 の時間を 30 分一定として粘度を測定し，図 7 および図 8 の結果 を得た。

図示したように，Na-PSS 扤よび Na-CS ともに，尿素濃度の 増加とともにその $\eta_{\mathrm{sp}} / c_{\mathrm{p}} \sim c_{\mathrm{p}}$ 曲線は規則的に上昇した。

そして Na-PSS の場合には，いずれの尿素濃度のときもその 曲線は汇淔線性を示し，たとえばポリビニルアルュールのよう な高分子非電解質にみられる ${ }^{15)}$ の同様の傾向を示した。しかし ポリビニルアルコールの場合の尿素濃度による粘度上昇の原因に ついては，その分子鎖沿沿って存在する $\mathrm{OH}$ 基間の分子内水素結 合が尿素によって切断されることもその一因をなすと説明されて いる ${ }^{15)}$ が，Na-PSS の場合には，このよ5な分子内水素結合は考 えられないので，前項で述べたように Na-PSS に対して尿素水 溶液が良溶媒として作用することが，尿素濃度による粘度上昇の

11) J.A.Rupley, J.Phys. Chem., 68, 2002 (1964).

12) A. Katayama, T. Matuura, K. Konishi, N. Kuroki, Kolloid-Z., 202, 157 (1965).

13) G.E. Walrafen, J.Chem. Phys., 44, 3726 (1966).

14) O.D. Bonner, G. B. Woolsey, J. Phys. Chem., 72, 899 (1968).

15）前田弘邦，河合 徹，関井澄生，高 分子化学， 15，719 (1958).

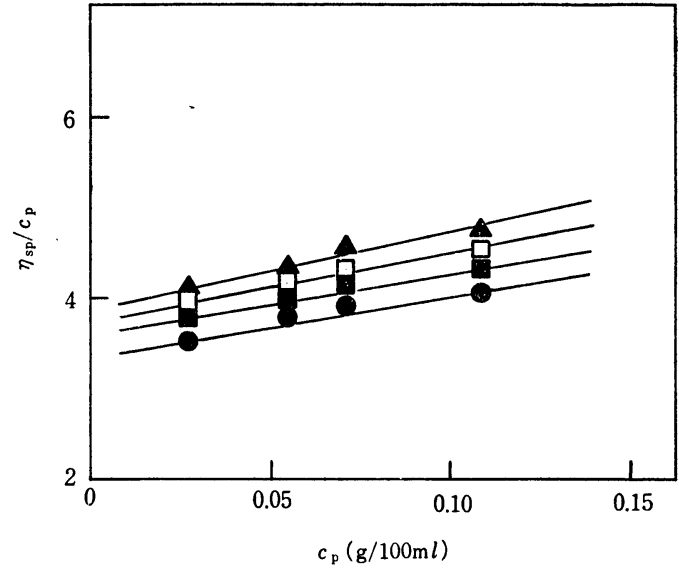

図 $7 \quad \eta_{\mathrm{sp}} / c_{\mathrm{p}} \sim c_{\mathrm{p}}$ 曲線に扣よぼす尿素濃度の影響 （尿素水溶液調製 30 分後, $\mathrm{Na}-\mathrm{PSS}-\mathrm{NaCl}$ 系） $\mathrm{NaCl} 6 \times 10^{-3} \mathrm{~mol} / l$ 一定

尿素濃度 $(\mathrm{mol} / \mathrm{l}) \bigcirc: 0,1, \square: 2, \boldsymbol{\Delta}: 3$

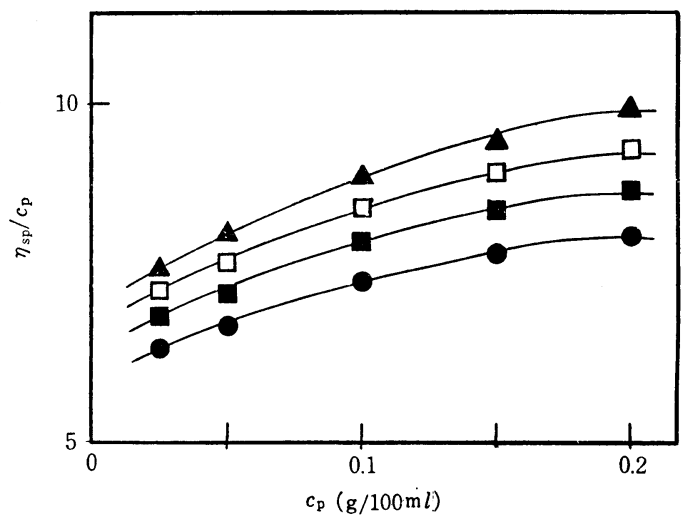

図 $8 \quad \eta_{\mathrm{sp}} / c_{\mathrm{p}} \sim c_{\mathrm{p}}$ 曲線に括よぼす尿素濃度の影響 （尿素水溶液調製後 30 分, $\mathrm{Na}-\mathrm{CS}-\mathrm{NaCl}$ 系）

$\mathrm{NaCl} 6 \times 10^{-3} \mathrm{~mol} / l$ 一定

尿素濃度 $(\mathrm{mol} / \mathrm{l}) \bigcirc: 0, \boldsymbol{\square}: 1, \square: 2, \boldsymbol{\Delta}: 3$

原因と考えられる。

また $\mathrm{Na}-\mathrm{CS}$ の場合にも，その $\eta_{\mathrm{sp}} / c_{\mathrm{p}} \sim c_{\mathrm{p}}$ 曲線が尿素濃度の増 加とともに上昇するのは，Na-PSS の場合と同様，尿素水溶液が 良溶媒として作用することが原因と考号られるが, その $\eta_{\mathrm{sp}} / c_{\mathrm{p}} \sim c_{\mathrm{p}}$ 曲線は Na-PSS の場合と異なり，いずれの尿素濃度のときも直 線性を示さず，上に凸型の曲線となり，また尿素濃度の増加によ るその上昇の程度は Na-PSS の場合よりも大きい。これは前項 にも述べたように，Na-CS の場合には考えられる分子内水素結 合の尿素による切断がその原因と思われる。

（昭和 44 年 10 月 17 日，日本化学会中国四国支部合同松山大会 講演）

終わりに試料を提供された三菱樹脂および山陽パルプの各社に 感謝する。 